\title{
TOTAL SODIUM, POTASSIUM AND CHLORIDE IN ADULT MAN ${ }^{1}$
}

\author{
By GILBERT B. FORBES AND ANNE M. LEWIS \\ (From the Department of Pediatrics, University of Rochester School of Medicine and \\ Dentistry, Rochester, N. Y.)
}

(Submitted for publication December 12, 1955 ; accepted February 9, 1956)

The development of the isotopic dilution method has brought about a renewed interest in the subject of total body composition, with the result that a considerable amount of information is now available on total exchangeable sodium, potassium, and chloride in man. The situation with regard to direct chemical analysis is quite different, however. Although a number of human fetuses and newborn babies have been analyzed for these three constituents (for references see 1), data for adult man are meager. Shohl has reported results of calculations based upon an examination of the older literature (2). Widdowson, McCance, and Spray (3) have analyzed three adult carcasses for a number of constituents, including $\mathrm{Na}$ and $\mathrm{K}$; only one of their subjects was free from serious disease, however.

The opportunity for adding to knowledge in this field presented itself recently when the carcasses of two adult males were made available for analysis. This report is concerned with total content of $\mathrm{Na}, \mathrm{K}$, and $\mathrm{Cl}$ in these two subjects; values for water and fat content are also included. Procedures used in preserving and later in dissecting the bodies have been presented elsewhere, and values for water, fat, protein, calcium, phosphorus, and total ash content are also given $(4,5)$.

\section{MATERIALS AND METHODS}

The first subject, hereinafter referred to as the 1951 specimen, was a white male, aged 46 years. He died as a result of a fractured skull. During the five days of hospitalization immediately preceding his death, he remained in an unconscious state, and all fluids were given intravenously. Data from the hospital records indicate an average daily intake during this period of $1900 \mathrm{cc}$. water, $65 \mathrm{gm}$. glucose, and $220 \mathrm{mEq}$. $\mathrm{Na}$ (as $\mathrm{NaCl}$ ). No information is available on the concentration of electrolytes in the blood, on the urinary output or frequency of stools. The only other medications listed are penicillin and Aminopyrine, the latter being given terminally for

1 Supported by grants from the Playtex Park Research Institute and Atomic Energy Commission, Contract No. AT (30-1) -1827, with the University of Rochester. elevated body temperature. At post-mortem examination the tissues appeared to be in a normal state of hydration and no abnormalities were noted aside from those due to cerebral injury and hypostatic pulmonary congestion.

Analysis of the carcass, carried out in R. M. Forbes' laboratory, revealed that the total body contained 2.98 per cent nitrogen, 5.43 per cent ash, 1.91 per cent calcium, and 0.92 per cent phosphorus (4).

The second subject (1953 specimen), estimated age 60 years, was found dead in a hotel room. At postmortem examination the following abnormalities were noted: arteriosclerosis of abdominal aorta and coronary arteries; hemorrhages in edges of mitral and tricuspid valves, but no definite endocarditis; moderate cardiac enlargement; moderate fatty degeneration of myocardium and liver; and marked passive congestion of both lungs.

Mensuration data are given in Table I.

The samples of soft tissue represented the entire organ, including blood, first diced, then thoroughly mixed, and a portion ground in a power grinder for analysis. The skeletal sample from the 1951 specimen consisted of representative portions of the entire skeleton (with marrow), ground as finely as possible with an iron mortar and pestle; that from the 1953 specimen consisted of all the skeleton (with marrow) except the tibia which was in a separate sample. Aliquots of the frozen tissues were shipped to us in dry ice by Air Express and kept frozen until analyzed. Water content was determined on duplicate samples by drying to constant weight in a vacuum oven at $65^{\circ} \mathrm{C.}$. This was usually accomplished in 48 hours. Neutral fat was extracted from the dried tissues for three 24-hour periods with dry ethyl ether at room temperature, after which they were redried and fat content determined by difference. Chloride, $\mathrm{Na}$, and $\mathrm{K}$ determinations were made on all extracts, and it was found that when suitable precautions were taken to avoid contamination with moisture there was no loss of electrolyte into the ether fraction. Appropriate corrections

TABLE I

Body measurements

\begin{tabular}{cccccc}
\hline \hline & & & $\begin{array}{c}\text { Chest } \\
\text { circum- } \\
\text { ference }\end{array}$ & $\begin{array}{c}\text { Bi- } \\
\text { acromial } \\
\text { width }\end{array}$ & $\begin{array}{c}\text { Bi- } \\
\text { iliac } \\
\text { width }\end{array}$ \\
\hline & $K_{\mathrm{g} .}$ & $\mathrm{cm}$. & $\mathrm{cm}$. & $\mathrm{cm}$. & $\mathrm{cm}$. \\
1951 Specimen & 53.8 & 168.5 & 78 & 38.4 & 29.3 \\
1953 Specimen & 73.5 & 172 & 95 & 39.5 & 29.5 \\
\hline
\end{tabular}

2 Special care was taken in drying tissues with high fat content to avoid boiling over. 
were made for the recoveries in the ether fraction in the few instances in which they occurred.

The duplicate samples of fat-free, dried soft tissue were digested with $\mathrm{HNO}_{3}$ in the presence of $\mathrm{AgNO}_{8}$ for determination of $\mathrm{Cl}$ by the Volhard titration method. Determinations of $\mathrm{Na}$ and $\mathrm{K}$ were made on aliquots of the $\mathrm{Cl}$ digest using a lithium internal standard flame photometer of the design of Berry, Chappell, and Barnes (6). In this instrument no interference of $\mathrm{Na}$ on $\mathrm{K}$ readings, or of $\mathrm{K}$ on $\mathrm{Na}$ readings, is detectable until the concentration of the interfering ion exceeds $20 \mathrm{mEq}$. per L. in the final solution as analyzed.

The fat-free dried skeletal samples were further ground to a fine powder with a porcelain mortar and pestle. Aliquots were digested for $\mathrm{Cl}$ analysis as described for the soft tissues. Other aliquots were ashed overnight in a muffle furnace at $525^{\circ} \mathrm{C}$., and amounts equivalent to 0.2 to $0.5 \mathrm{gm}$. of wet bone introduced into an ion-exchange resin column for separation of $\mathrm{Na}$ from $\mathrm{Ca}$, as described in previous publications, $(7,8)$. Concentrations of $\mathrm{Na}$ and $\mathrm{K}$ in the appropriate fractions of eluate were then determined with the above mentioned flame photometer. No corrections for $\mathrm{Na}$ readings were necessary in view of the absence of $\mathrm{P}, \mathrm{K}, \mathrm{Mg}, \mathrm{Ca}$ and strong acid from the solution as analyzed. Since $\mathrm{Ca}$ was present in the $\mathrm{K}$ fraction, $\mathrm{Ca}$ was first determined on an aliquot of the original ash solution by a modification of the semi-micro method of Kochakian and Fox (9) using nitroferroin (5-nitro-1,10-phenanthroline ferrous complex) as an indicator. The apparent $\mathrm{K}$ values obtained were then corrected according to a predetermined curve for known $\mathrm{K}: \mathrm{Ca}$ solutions. The true values for $\mathrm{K}$ ranged as high as 133 per cent of the apparent values read on the photometer.

\section{RESULTS}

Analytical values are presented in Table II. Blood present in the heart and great vessels is included in the category labelled "remainder." Blood was not removed from the organs prior to analysis, nor were concentration values for serum electrolytes available. The category labelled "muscle" includes the entire muscle mass together with fibrous tissue and smaller tendons and ligaments; the larger tendons are included in the "remainder." It is evident, therefore, that our results for muscle cannot be compared to those based on biopsy specimens or from bled animals. Nor is it possible to calculate apparent "extracellular" and "intracellular" volumes.

It should be noted that certain organs were not included in the analysis. For the 1953 specimen these comprised the bile and contents of bladder and alimentary tract, totalling 396 grams in weight, and the spleen, pancreas, thyroid, adrenal, hair, and nails totalling 211 grams. For the 1951 specimen these comprised the bile and contents of the bladder and alimentary tract, 532 grams, and the spleen, pancreas, kidney, hair, and nails, totalling 453 grams. Of these, only the kidney constitutes a significant portion of the total body weight. Values for water and fat content are available for this organ (5) ; those for $\mathrm{Na}, \mathrm{Cl}$ and $\mathrm{K}$ were calculated from Shohl's tables (2). Considering that the contents of the biliary, alimentary and genitourinary tracts need not have been included, the analysis comprised 99.7 and 99.0 per cent, respectively, of the two specimens.

\section{DISCUSSION}

\section{Comparison with published data}

In Table III we have summarized the values obtained in our subjects for comparison with those reported by Widdowson, McCance, and Spray (3) and Shohl (2). There is good agreement as to total content of water and potassium. The remarkable similarity between the results of modern analytical techniques and those obtained by earlier workers, as reported by Shohl (2), is noteworthy.

The greatest discrepancies among the values listed in Table III concern sodium. Shohl's figure of $39 \mathrm{mEq}$. per $\mathrm{Kg}$. body weight must be considered too low in view of the results of isotopic dilution studies. Total exchangeable $\mathrm{Na}$ is of the order of $42 \mathrm{mEq}$. per $\mathrm{Kg}$. (av.) in adult males, and it is known that the procedure used in arriving at this value underestimates true total $\mathrm{Na}$ in the adult (11). Perhaps analytical difficulties in determining $\mathrm{Na}$ content of calcified tissues (7) are responsible for the low value reported by Shohl. On the other hand, Widdowson, McCance, and Spray give a figure of $74 \mathrm{mEq}$. per $\mathrm{Kg}$., a value considerably in excess of those for our subjects. Their subject committed suicide by drowning, and it is not stated whether this incident occurred in fresh or salt water. If the latter, the aspiration of only 1.5 liters of sea water would have been sufficient to account for the difference between the $\mathrm{Na}$ content of Widdowson, McCance, and Spray's subject and ours. ${ }^{8}$

Perhaps the greatest source of error in a study of this sort is that associated with sampling of the

3 This contention receives support from the calculation that this same quantity of sea water very nicely accounts for the observed differences in water content. 


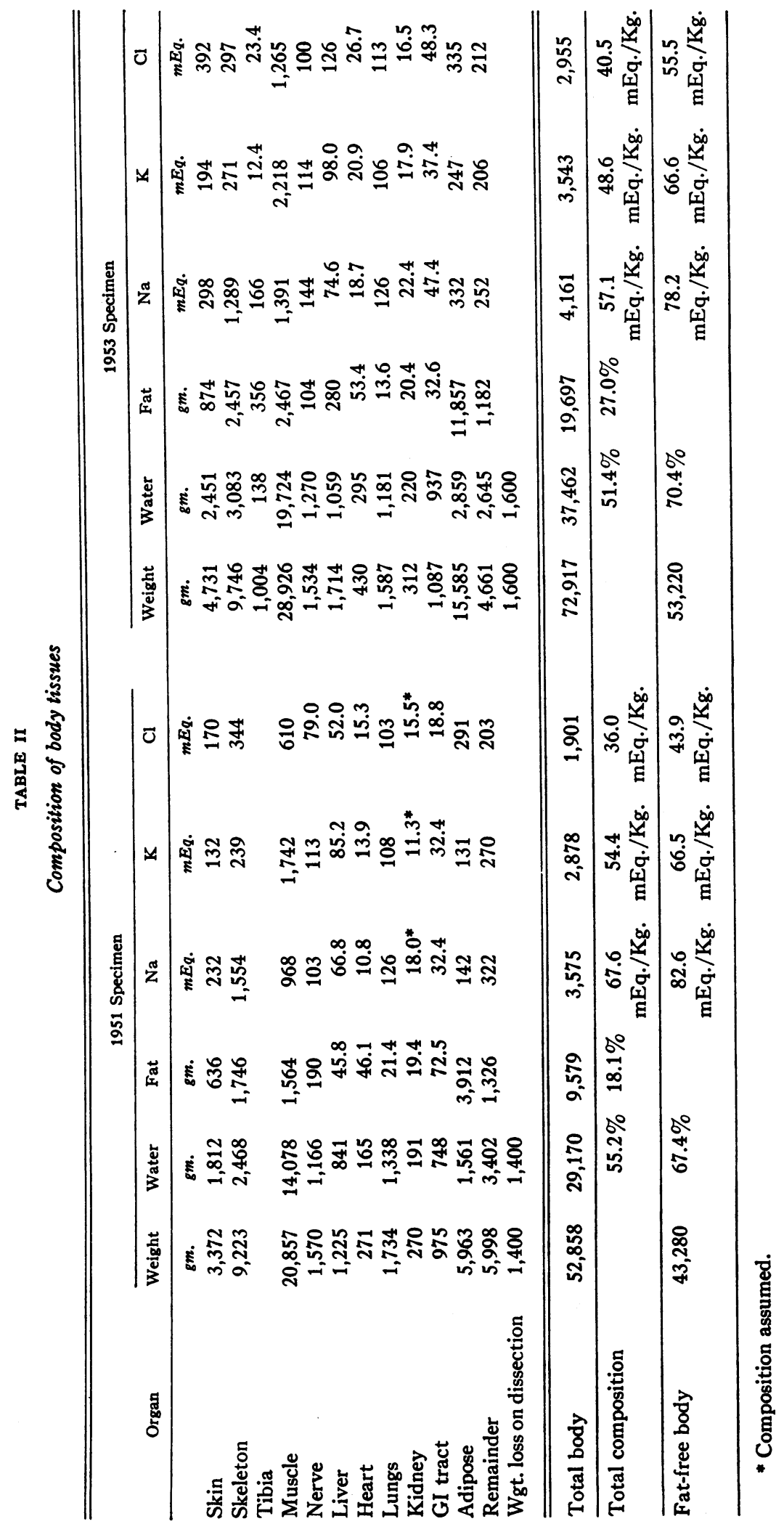


TABLE IIIA

Total body content

\begin{tabular}{|c|c|c|c|c|c|c|c|c|c|c|c|}
\hline \multirow[b]{2}{*}{ Subject } & \multirow[b]{2}{*}{$\begin{array}{l}\text { Age } \\
\text { Sex }\end{array}$} & \multirow[b]{2}{*}{ Weight } & \multirow[b]{2}{*}{$\begin{array}{l}\text { Per cent } \\
\text { fat }\end{array}$} & \multicolumn{4}{|c|}{ Fresh weight basis } & \multicolumn{4}{|c|}{ Fat-free basis } \\
\hline & & & & $\begin{array}{c}\text { Per cent } \\
\mathrm{H}_{2} \mathrm{O}\end{array}$ & $\mathbf{N a}$ & $\mathrm{Cl}$ & $\mathbf{K}$ & $\begin{array}{c}\text { Per cent } \\
\mathrm{H}_{2} \mathrm{O}\end{array}$ & $\mathrm{Na}$ & $\mathrm{Cl}$ & $\mathbf{K}$ \\
\hline 1951 & $46 \mathrm{M}$ & $\begin{array}{r}K_{g} \\
53.8\end{array}$ & $\begin{array}{l}18.1 \\
(19.4)^{*}\end{array}$ & $\begin{array}{l}55.2 \\
(55.1)^{*}\end{array}$ & $\begin{array}{c}m E q . / K_{g} \\
67.6\end{array}$ & $\begin{array}{c}m E q . / K_{g} \\
36.0\end{array}$ & $\begin{array}{c}m E_{q .} / \mathrm{Kg}_{\mathrm{g}} \\
54.4\end{array}$ & 67.4 & $\begin{array}{c}m E q . / K_{g} \\
82.6\end{array}$ & $\begin{array}{c}m E q . / K_{g} \\
43.9\end{array}$ & $\begin{array}{c}m E_{q .} / \mathrm{Kg}_{\mathrm{g}} \\
66.5\end{array}$ \\
\hline 1953 & $60 \mathrm{M}$ & 73.5 & $\begin{array}{l}27.0 \\
(27.3)^{*}\end{array}$ & $\begin{array}{c}51.4 \\
(51.6)^{*}\end{array}$ & 57.1 & 40.5 & 48.6 & 70.4 & 78.2 & 55.5 & 66.6 \\
\hline $\begin{array}{l}\text { Widdowson, } \\
\text { McCance, } \\
\text { and } \\
\text { Spray (3), } \\
\text { Subject "L"' }\end{array}$ & $42 \mathrm{~F}$ & 45.1 & 23.6 & 56.0 & 73.7 & & 55.5 & 73.2 & 96.5 & & 72.6 \\
\hline Shohl (2) & Adult & 70.0 & 18.0 & 59.1 & 39.1 & 34.2 & 54.8 & 72.1 & 47.7 & 41.2 & 66.8 \\
\hline
\end{tabular}

* Data from R. M. Forbes' laboratory.

TABLE IIIB

Isotopic dilution data (from the literature) *

\begin{tabular}{|c|c|c|c|c|}
\hline Subjects & $\begin{array}{c}\text { Per cent } \\
\text { H:O }\end{array}$ & $\mathbf{N a}$ & $\mathrm{Cl}$ & $\mathbf{K}$ \\
\hline Young adult males $(10,11,13-15)$ & $\begin{array}{r}61.1 \\
\pm 4.4\end{array}$ & $\begin{array}{c}m E q . / K_{g} \\
41.9 \\
\pm 5.6\end{array}$ & $\begin{array}{c}m E q . / K_{g} \\
32.1 \\
\pm 3.8 \\
31.6 \\
\pm 3.8\end{array}$ & $\begin{array}{r}m E_{q .} / K_{g} \\
46.3 \\
\pm 4.3\end{array}$ \\
\hline Males $34-54$ years $(10,12)$ & $\begin{array}{r}55.4 \\
\pm 5.4\end{array}$ & $\begin{array}{r}43.4 \\
\pm 4.9\end{array}$ & & \\
\hline Males over 50 years $(10,12)$ & $\begin{array}{r}54.3 \\
\pm 6.2\end{array}$ & $\begin{array}{r}40.9 \\
\pm 5.1\end{array}$ & & \\
\hline
\end{tabular}

* Values expressed as the mean \pm one standard deviation.

tissues to be analyzed. In an attempt to evaluate this factor, results for water and fat content obtained in R. M. Forbes' laboratory are also included in Table III $(4,5)$. Since his analyses were made on aliquots other than those shipped to our laboratory, the similarity between the two sets of results would speak against gross errors in sampling.

\section{Comparison with results of isotopic dilution studies}

Published information on total body water, as measured by deuterium dilution, and total exchangeable sodium, chloride and potassium is included in Table III for comparative purposes. Each of these values was arrived at through study of a number of subjects. Taking the mean values, it is evident that there is excellent agreement between carcass analysis and deuterium dilution for body water but that the dilution techniques may well underestimate true total body content for $\mathrm{Na}$, $\mathrm{Cl}$ and $\mathrm{K}$. The discrepancy is greatest in the case of $\mathrm{Na}$, the data for our two subjects indicating that only 68 per cent of total $\mathrm{Na}$ is exchangeable, a value quite similar to that obtained in the rabbit (16). Total $\mathrm{Cl}$ and $\mathrm{K}$ by carcass analysis exceed the mean values obtained by isotopic dilution though still within the reported range of variation by the latter method. In view of the paucity of carcass analyses, however, formal statistical comparisons would not be justified.

\section{Evaluation of our subjects}

Although it cannot be stated that the subjects employed in this study were completely normal with respect to fluid and electrolyte metabolism, the available information would indicate that they 
did not suffer from serious imbalance. The 1951 specimen appeared in good physical condition, although 22 per cent underweight according to the Metropolitan Life tables. It is entirely possible that his illness and the therapy employed had some effect on electrolyte and fluid balance, since the lungs were increased in weight. Despite the administration of generous amounts of salt, there was no evidence of gross edema, nor did the lungs contain an excessive amount of water (77 per cent, which is equal to Shohl's figure). A variety of metabolic disturbances have been described as occurring in association with cerebral injury (17).

Nothing is known of the circumstances surrounding the death of the 1953 subject, although it is likely that disease of the coronary arteries was a major factor. Pulmonary congestion was present, and this autopsy finding is substantiated by the excessive weight of the lungs. Weight and height were well within the range of normal.

Both subjects appeared to be in a normal state of hydration at the time of autopsy, although the possibility of a moderate degree of salt retention in each cannot be excluded.

\section{SUMMARY}

Analyses of two adult male carcasses have been made for total content of water, fat, sodium, potassium and chloride.

Results of our analyses have been compared with data from the literature.

\section{ACKNOWLEDGMENT}

The authors wish to acknowledge the generous cooperation of Professor R. M. Forbes, College of Agriculture, University of Illinois, in providing the tissue samples for analysis.

\section{REFERENCES}

1. Forbes, G. B., Inorganic chemical heterogony in man and animals. Growth, 1955, 19, 75.

2. Shohl, A. T., Mineral Metabolism, New York, Reinhold Publishing Corp., 1939, p. 19.
3. Widdowson, E. M., McCance, R. A., and Spray, C. M., The chemical composition of the human body. Clin. Sc., 1951, 10, 113.

4. Forbes, R. M., Cooper, A. R., and Mitchell, H. H., The composition of the adult human body as determined by chemical analysis. J. Biol. Chem., 1953, 203, 359.

5. Forbes, R. M., Personal communication.

6. Berry, J. W., Chappell, D. G., and Barnes, R. B., Improved method of flame photometry. Indust. \& Engin. Chem., Anal. Ed., 1946, 18, 19.

7. Forbes, G. B., and D'Ambruso, M., Determination of sodium in bone with the aid of cation exchange chromatography. J. Biol. Chem., 1955, 212, 655 .

8. Forbes, G. B., and Lewis, A., Determination of specific activity of sodium in bone. Proc. Soc. Exper. Biol. \& Med., 1955, 90, 178.

9. Kochakian, C. D., and Fox, R. P., Microdetermination of calcium by titration of the oxalate with ammonium hexanitratocerate. Indust. \& Engin. Chem., Anal. Ed., 1944, 16, 762.

10. Edelman, I. S., Haley, H. B., Schloerb, P. R., Sheldon, D. B., Friis-Hansen, B. J., Stoll, G., and Moore, F. D., Further observations on total body water: I. Normal values throughout the life span. Surg., Gynec. \& Obst., 1952, 95, 1.

11. Forbes, G. B., and Perley, A., Estimation of total body sodium by isotopic dilution. I. Studies on young adults. J. Clin. Invest., 1951, 30, 558.

12. Edelman, I. S., James, A. H., Brooks, L., and Moore, F. D., Body sodium and potassium. IV. The normal total exchangeable sodium; its measurement and magnitude. Metabolism, 1954, 3, 530.

13. Reid, A. F., Forbes, G. B., Bondurant, J., and Etheridge, J., Estimation of total body chloride in man by radiobromide dilution. J. Lab. \& Clin. Med., In press.

14. Dunning, M. F., Steele, J. M., and Berger, E. Y., Measurement of total body chloride. Proc. Soc. Exper. Biol. \& Med., 1951, 77, 854.

15. Corsa, L., Jr., Olney, J. M., Jr., Steenburg, R. W., Ball, M. R., and Moore, F. D., The measurement of exchangeable potassium in man by isotope dilution. J. Clin. Invest., 1950, 29, 1280.

16. Davies, R. E., Kornberg, H. L., and Wilson, G. M., Relation between total and exchangeable sodium in the body. Nature, 1952, 170, 979.

17. Higgins, G., O'Brien, J. R. P., Lewin, W., and Taylor, W. H., Metabolic disorders in head injury, Survey of 76 consecutive cases. Lancet, 1954, 1, 61. 